\title{
EPISTEMOLOGI PENDIDIKAN ISLAM PERSPEKTIF ABUDDIN NATA
}

\author{
Ramli Poloso \\ Institust Agama Islam Negeri (IAIN) Sultan Amai Gorontalo \\ (Ramli.poloso@yahoo.com)
}

\begin{abstract}
Abstrak
Epistemologi pendidikan Islam Abuddin Nata mengandung muatan humanis yaitu sebuah rumusan pendidikan Islam yang memaksimalkan potensi dan kemampuan akal manusia sebagai makhluk yang sempurna dengan tetap bersandar dan berpijak pada al-Qurean dan Sunnah. Pola pendidikan Islam yang humanis tersebut menghendaki pola theo-antrophocentries yaitu memadukan usaha manusia dengan izin dan kehendak Allah swt. Selain itu, Abuddin Nata menginginkan sebuah model pendidikan Islam yaitu pendidikan Islam yang integralistik-konvergensi. Pendidikan Islam integralistik-konvergensi yang dimaksud adalah keterpaduan dan kesatuan antara konsep al-Qur"an dan Sunnah dengan konteks keindonesiaan sehingga mengarah pada satu tujuan mewujudkan kehidupan yang madani.

Abuddin Nata thinking about Islam carries with humanist education which is an educational formula that maximizes the potential of the human mind as a perfect being to keep leaning on the Qur'an and Sunnah. This requires that in formulating education shall be directed to develop and foster the existing potential to become effective and efficient. To reinforce this concept, Abuddin Nata proposed learning strategy with two models based on the educator (teacher centered) and centered on the learner (student centered). The challenge of Islamic Education in the era of globalization today is the integralistic education model. Integralistic education is education that brings together and integrates the concept of Islamic education and receive all the positive valued result of globalization by always grounded in the glorious values of Islam, Quran and Sunnah. In addition, character education is a model of education that is relevant to the times today. character education is not just a question of good and bad, but the effort to change the nature, character and mental state of a person in accordance with the noble values and commendable.
\end{abstract}

Kata Kunci: Epistemologi, Pendidikan Islam

\section{A. Pendahuluan}

Islam merupakan agama yang mewarisi tradisi intelektual dari berbagai peradaban besar dunia sebelumnya seperti Yunani Kuno, Romawi dan Persia. ${ }^{1}$ Islam menjadi payung tempat berteduhnya berbagai tradisi intelektual yang seolah menemukan hidup baru yang bertransformasi dalam wujud yang baru. Hal ini menjadi bantahan atau jawaban atas dugaan bahwa Islam hanya sebagai jembatan yang dilalui oleh peradaban Yunani Kuno dan Persia menuju daratan Eropa. Kehadiran Islam merupakan semangat baru bagi perkembangan ilmu pengetahuan di dunia. Tentu tidak dapat dipungkiri sumbangsih Islam dalam percaturan ilmu pengetahuan dibelahan bumi manapun.

\footnotetext{
${ }^{1}$ Hasan Langgulung, Asas-asas Pendidikan Islam, Cet. ke-5, (Jakarta: PT. Pustaka Al Husna Baru, 2003), h. 26 .
} 
Perkembangan ilmu pengetahuan terjadi dan dapat dirasakan pada masa pemerintahan Daulah Bani Abbasiyah pada pemerintahan khalifah Harun ar-Rasyid yang mampu menjadikan kota Baghdad sebagai pusat peradaban ilmu pengetahuan. ${ }^{2}$ Perkembangan ilmu saat itu berjalan seimbang baik ilmu pengetahuan umum seperti: kimia, fisika, astronomi, kedokteran, aljabar dan lain-lain. Sedangkan dalam ilmu pengetahuan agama seperti: tafsir, hadits, fiqih, ushul fiqhi dan bidang lainnya.

Indonesia adalah salah satu negara yang sedang berkembang dalam segala sektor kehidupan. Untuk menjadi negara yang berkembang, tidak lepas dari sumber daya manusia yang memadai. Sumber daya manusia (SDM) merupakan salah satu faktor pendukung dari kemajuan dan perkembangan tersebut. Sumber daya manusia memiliki peran disamping sumber daya alam, karena keduanya memiliki keterkaitan yang sangat erat. Sumber daya manusia yang diharapkan tersebut adalah manusia-manusia yang memiliki visi perubahan (Agent Of Sosial Change) yang merupakan generasi harapan bangsa ${ }^{3}$. Sumber daya manusia yang berkualitas tidak terlepas dari peran penting dunia pendidikan. Kualitas sumber daya manusia yang hendak dibentuk tentu harus sesuai dengan perkembangan dan mampu menjawab tantangan zaman dewasa ini.

Lembaga pendidikan merupakan hal yang tidak dapat dilepaskan dari sisi kehidupan manusia. Pendidikan adalah instrumen yang berfungsi sebagai "memanusiakan manusia". Dalam arti menempatkan manusia sebagai makhluk yang pada dasarnya memiliki banyak potensi dan kemampuan. Selain itu, pendidikan juga merupakan sarana bagi manusia untuk mengetahui sesuatu perkara yang belum diketahui sebelumnya.

Pendidikan Islam dalam konteks ini merupakan upaya yang ditujukan ke arah pengembangan potensi yang dimiliki manusia secara maksimal sehingga dapat diwujudkan dalam bentuk kongkret. ${ }^{4}$ Dengan demikian, manusia memiliki kemampuan untuk menciptakan sesuatu yang bermanfaat bagi diri, keluarga, masyarakat dan lingkungannya sebagai realisasi fungsi dan tujuan penciptaannya baik sebagai pemimpin (khalifah) dan hamba (,abid) Allah swt.

Pendidikan adalah model rekayasa sosial yang paling efektif untuk mewujudkan generasi yang unggul dimasa depan nantinya. ${ }^{5}$ Hal ini menunjukkan bahwa pendidikan menempati posisi yang sangat strategis dalam membentuk manusia yang ideal dan unggul

\footnotetext{
${ }^{2}$ Badri Yatim, Sejarah Peradaban Islam: Dirasah Islamiyah II, (Jakarta: PT Raja Grafindo Persada, 2005), h. 61.

${ }^{3}$ Muhammad Munir dan Wahyu Ilaihi, Managemen Dakwah, Cet. Ke-2, (Jakarta: Kencana Prenada Media Grup, 2009), h. 270.

${ }^{4}$ Bukhari Umar, Ilmu Pendidikan Islam, Cet. ke-2, (Jakarta: Amzah, 2011), h. 15.

${ }^{5}$ Abdul Munir Mulkhan, Paradigma Intelektual Muslim, Cet. ke-1, (Yogyakarta: Sipres, 1993), h. v.
} 
dalam segala aspek. Oleh karena itu, tidak berlebihan jika dikatakan bahwa pembentukan manusia yang ideal dan unggul tidak dapat lepaskan dan jauh dari yang namanya pendidikan.

Fenomena yang dapat disaksikan dewasa ini yaitu pendidikan merupakan persoalan yang tidak pernah selesai dibicarakan. Tentu hal ini dapat dilihat dengan berbagai macam kurikulum yang diperbaharui demi untuk mencapai tujuan yang diinginkan yaitu mencerdaskan kehidupan bangsa.

Ada tiga masalah utama sampai pendidikan menjadi sebuah masalah yang tidak pernah selesai dibicarakan; 1) setiap orang menginginkan sesuatu yang lebih baik. Itulah fitrah manusia menginginkan pendidikan yang lebih baik; 2) teori pendidikan dan teori pada umumnya disesuaikan dengan apa yang dibutuhkan oleh masyarakat. Sebab kebutuhan masyarakat selalu berubah-ubah sesuai tempat dan waktu. Apabila teori pendidikan tidak sesuai dengan teori pada masyarakat, inilah yang menyebabkan terjadi kesenjangan antara harapan dan kenyataan; 3) pengaruh pandangan hidup setiap orang. Setiap orang tentu memiliki paradigma yang berbeda-beda tentang pendidikan. Sehingga sangat sulit untuk menyatukan berbagai pandangan tersebut dalam satu konsep yang sama. ${ }^{6}$

Berdasarkan pendapat di atas, dapat diambil sebuah kesimpulan bahwa sangat perlu merumuskan sebuah konsep pendidikan yang dapat menjawab semua kebutuhan masyarakat. Tanpa melihat suku, budaya dan bahasa masyarakat setempat. Sehingga tidak terjadi kesenjangan antara konsep pendidikan dan kebutuhan masyarakat.

Dalam Undang-undang Republik Indonesia No. 20 tahun 2003 dikemukakan bahwa: pendidikan nasional bertujuan mengembangkan potensi peserta didik agar menjadi manusia yang beriman dan bertakwa kepada Tuhan Yang Maha Esa, berakhlak mulia, sehat, berilmu, cakap, kreatif, mandiri dan menjadi warga negara yang demokratis dan bertanggung jawab dalam rangka mencerdaskan kehidupan bangsa. ${ }^{7}$

Berdasarkan amanah undang-undang Republik Indonesia No. 20 tahun 2003 tentang sistem pendidikan, maka menurut hemat saya ada dua hal pokok yang harus menjadi sasaran utama dalam proses pelaksanaan pendidikan yaitu mutu (kualitas) pendidikan dan strategi pembelajaran. Kedua hal ini kelak yang akan mengantarkan pada tujuan pendidikan yang ingin dicapai.

\footnotetext{
${ }^{6}$ Ahmad Tafsir, Filsafat Pendidikan Islam, Cet. ke-5, (Bandung: PT Remaja Rosdakarya, 2012), h. 40-41.

${ }^{7}$ Undang-undang Republik Indonesia No. 20 tahun 2003 tentang Sistem Pendidikan Nasional.
} 
FARABI

Jurnal Pemikiran Konstruktif Bidang Filsafat dan Dakwah

ISSN $1907-0993$

E ISSN $2442-8264$

Vol. 18 No. 2, Desember 2018

\section{B. Dasar, Sumber dan Prinsip Pendidikan Islam Perspektif Abuddin Nata}

a) Dasar Pendidikan Islam

Adapun yang dimaksud dengan dasar pendidikan adalah pandangan hidup yang melandasi seluruh aktivitas dan kegiatan setiap manusia dalam hidup bermasyarakat dan bernegara. Karena dasar merupakan hal yang fundamental, maka memerlukan pandangan hidup yang kokoh dan komprehensif. Dengan demikian, dasar dalam sebuah pendidikan ialah bersifat filosofis, sehingga akan melahirkan yang disebut dengan filsafat pendidikan. ${ }^{8}$

Lebih lanjut Abuddin Nata mengemukakan bahwa ada beberapa dasar dalam pendidikan yang harus dipahami oleh setiap penyelenggara pendidikan dan pendidik. Sehingga akan melahirkan manusia-manusia yang memiliki kecerdasan

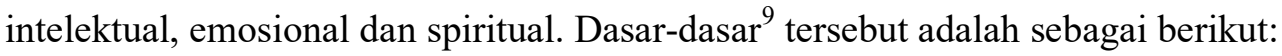

1) Dasar kemanusiaan.

2) Dasar kesatuan umat manusia.

3) Dasar keseimbangan.

4) Dasar rahmat bagi semseta alam.

Selain keempat penjelasan tersebut di atas, Abuddin Nata mengklasifikasikannya menjadi tiga dasar utama dalam pendidikan Islam yaitu dasar religius, dasar filsafat dan dasar ilmu pengetahuan. ${ }^{10}$ Dasar religius bersumber dari wahyu yaitu al-Qur"an dan Sunnah, dasar filsafat bersumber dari pemikiran filsafat (intuisi dan perenungan) dan dasar ilmu pengetahuan bersumber dari hasil penelitian (riset dan eksperimen) fenomena alam dan sosial.

b) Sumber Pendidikan Islam

Pada dasarnya, yang menjadi sumber pendidikan Islam adalah al-Qurean, Sunnah, perkataan sahabat Nabi saw dan sejarah Islam. ${ }^{11}$ Adapun penjelasannya sebagai berikut:

1) Al-Qur"an. Sebagai sumber Islam yang pertama dan utama al-Qur"an dalam pendidikan Islam.

2) Sunnah. Sebagai sumber Islam yang kedua juga mengisyaratkan tentang adanya pendidikan.

3) Perkataan Sahabat Nabi saw.

\footnotetext{
${ }^{8}$ Abuddin Nata, Filsafat Pendidikan Islam Edisi Baru, (Jakarta: Gaya Media Pratama, 2005), h. 59.

${ }^{9}$ Ibid. h. 62-64.

${ }^{10}$ Abuddin Nata, Ilmu Pendidikan Islam Edisi Pertama, h. 91-96.

${ }^{11}$ Ibid. h. 75-83.
} 
4) Sejarah Islam.

c) Prinsip Pendidikan Islam

Abuddin Nata mengemukakan bahwa ada beberapa prinsip dalam pendidikan Islam yang juga merupakan prinsip yang diajarkan oleh al-Qur an dan Sunnah. Prinsip-prinsip ${ }^{12}$ tersebut sebagai berikut:

1) Prinsip pendidikan wajib belajar dan mengajar.

2) Prinsip pendidikan untuk semua.

3) Prinsip pendidikan sepanjang hayat.

4) Prinsip pendidikan berwawasan global.

5) Prinsip pendidikan integralistik dan seimbang.

6) Prinsip pendidikan yang sesuai dengan bakat manusia.

7) Prinsip pendidikan yang berbasis riset dan rencana.

8) Prinsip pendidikan yang unggul dan profesional.

9) Prinsip pendidikan yang berbasis masyarakat.

10) Prinsip pendidikan yang sesuai dengan perkembangan zaman.

Berdasarkan beberapa prinsip di atas, maka dipahami bahwa nilai-nilai pokok dalam Islam harus menjadi acuan dalam proses pendidikan. Sehingga hal itu akan membedakan antara pendidikan Islam dan pendidikan di luar Islam. Terutama bisa melahirkan lulusan pendidikan Islam yang berkarakter. Selain itu juga, prinsip pendidikan Islam merupakan upaya untuk mewujudkan cita-cita ideal Islam yaitu menjadi rahmat bagi alam semesta.

\section{Visi, Misi dan Sifat Pendidikan Islam Perspektif Abuddin Nata}

a) Visi Pendidikan Islam

Abuddin Nata berpendapat bahwa visi lahir dari hasil dialektika antara realitas dan idealitas. Sebagai contoh: ketika bangsa Indonesia menyatakan kemerdekaannya, maka yang pertama kali dirumuskan oleh para pemangku kepentingan negara ini adalah merumuskan visi negara Indonesia. ${ }^{13}$

Apabila konsep visi tersebut dihubungkan dengan pendidikan Islam, maka visi pendidikan Islam dapat diartikan sebagai sumber motivasi dan inspirasi dalam merumuskan misi, tujuan, kurikulum, proses belajar, guru, murid, manajemen dan

\footnotetext{
${ }^{12}$ Ibid. h. 103-116.

${ }^{13}$ Abuddin Nata, Ilmu Pendidikan Islam Edisi Pertama, h. 41.
} 
FARABI

Jurnal Pemikiran Konstruktif Bidang Filsafat dan Dakwah

ISSN $1907-0993$

E ISSN $2442-8264$

Vol. 18 No. 2, Desember 2018

lingkungan. Dengan demikian, visi pendidikan Islam dapat dirumuskan yaitu menjadikan pendidikan Islam sebagai tatanan yang kuat, berwibawa, efektif dan kredibel dalam mewujudkan cita-cita ajaran Islam. ${ }^{14}$

b) Misi Pendidikan Islam

Kata misi berasal dari kata mission yang berarti tugas, utusan atau misi. ${ }^{15}$ Dari pengertian tersebut dapat dipahami bahwa misi adalah tugas atau pekerjaan yang harus dilaksanakan dalam rangka mewujudkan visi yang telah ditetapkan. Dengan demikian, antara visi dan misi harus memiliki hubungan yang sangat erat yaitu fungsional simbiotik yang berarti saling mengisi dan memiliki umpan balik. Visi adalah sesuatu yang ingin dicapai dan misi adalah sarana atau jalan untuk mewujudkan visi tersebut. ${ }^{16}$

Ada beberapa misi pendidikan Islam yang dirumuskan oleh Abuddin Nata sebagai berikut:

a) Mendorong timbulnya kesadaran umat manusia agar mau melakukan kegiatan belajar dan mengajar.

b) Melaksanakan kegiatan belajar mengajar sepanjang hayat.

c) Melaksanakan program wajib belajar.

d) Melaksanakan program pendidikan anak usia dini (PAUD).

e) Mengeluarkan umat manusia dari kegelapan menuju kehidupan yang terang benderang.

f) Memberantas sikap jahiliyah.

g) Menyelamatkan manusia dari tepi jurang kehancuran yang disebabkan oleh pertikaian dan perselisihan.

h) Melakukan pencerahan batin kepada manusia agar sehat rohani dan jasmani.

i) Menyadarkan manusia agar tidak melakukan perbuatan yang dapat menimbulkan bencana di muka bumi.

j) Mengangkat harkat dan martabat manusia sebagai makhluk yang paling sempurna dalam ciptaan Allah swt. ${ }^{17}$

Berdasarkan uraian tersebut, nampak bahwa semua misi dalam pendidikan Islam yang hendak dikemukakan oleh Abuddin Nata identik dengan pendekatan normatif yaitu sesuai dengan apa yang termaktub dalam al-Qur"an sebagai pedoman hidup umat manusia.

\footnotetext{
${ }^{14}$ Ibid. h. 44.

${ }^{15}$ John M. Echols dan Hasan Shadily, Kamus Inggris Indonesia, h. 383.

${ }^{16}$ Abuddin Nata, Ilmu Pendidikan Islam Edisi Pertama, h. 45.

${ }^{17}$ Ibid. h. 45-53.
} 
c) Sifat Pendidikan Islam

Abuddin Nata mengemukakan bahwa pada dasarnya sifat dari pendidikan Islam sama dengan sifat ajaran Islam itu sendiri. Sebab pendidikan Islam berdasar pada alQurean dan Sunnah. ${ }^{18}$

Ada beberapa sifat pendidikan Islam yang harus dipahami secara universal demi mewujudkan visi dan misi pendidikan Islam sebagai berikut:

1) Sifat pendidikan Islam harus terbuka. ${ }^{19}$

2) Sifat pendidikan Islam harus fleksibel. ${ }^{20}$

3) Sifat pendidikan Islam harus seimbang (tawazun). ${ }^{21}$

4) Sifat pendidikan Islam harus Rabbaniyah. ${ }^{22}$

5) Sifat pendidikan Islam harus demokratis, sepanjang hayat, unggul dan memberdayakan. $^{23}$

Berdasarkan beberapa sifat tersebut di atas, jelaslah bahwa secara konseptual pendidikan Islam adalah pendidikan yang memenuhi segala aspek persyaratan yang dibutuhkan untuk memajukan suatu bangsa dan masyarakat yang maju. Oleh karenanya harus memperhatikan aspek mutu dan kualitas pendidikan yang dapat mencerdaskan kehidupan bermasyarakat, berbangsa dan bernegara.

\section{Tujuan Pendidikan Islam Perspektif Abuddin Nata}

Tujuan pendidikan Islam memiliki ruang lingkup dan cakupan yang sangat luas. Ada enam tahapan tujuan pendidikan Islam yang ditawarkan oleh Abuddin Nata sebagai berikut:

a) Tujuan Pendidikan Islam secara Universal

Tujuan pendidikan Islam secara universal yaitu harus ditujukan untuk menciptakan keseimbangan kepribadian manusia secara menyeluruh dengan cara melatih jiwa, akal pikiran, perasaan dan fisik manusia. ${ }^{24}$

Tujuan pendidikan Islam yang bersifat universal tersebut memiliki dua ciri yaitu: 1) mengandung prinsip universal antara aspek akidah, ibadah, muamalah, keseimbangan antara pribadi, kelompok dan kebudayaan, memiliki kejelasan baik aspek jiwa manusia

\footnotetext{
${ }^{18}$ Abuddin Nata, Filsafat Pendidikan Islam Edisi Baru, h. 46.

${ }^{19}$ Ibid. h. 46.

${ }^{20}$ Ibid. h. 48.

${ }^{21}$ Ibid. h. 51.

${ }^{22}$ Ibid. h. 52.

${ }^{23}$ Ibid. h. 54.

${ }^{24}$ Lihat H.M. Arifin, Ilmu Pendidikan Islam: Suatu Tinjauan Teoritis dan Praktik Berdasarkan Pendekatan Interdisipliner, (Jakarta: Bina Aksara, 1991), h. 40.
} 
FARABI

Jurnal Pemikiran Konstruktif Bidang Filsafat dan Dakwah

ISSN $1907-0993$

E ISSN $2442-8264$

Vol. 18 No. 2, Desember 2018

dan hukum setiap masalah. 2) mengandung keinginan untuk mewujudkan manusia yang sempurna, menjalankan tugas sebagai hamba, khalifah dan pewaris Nabi. ${ }^{25}$

b) Tujuan Pendidikan Islam secara Nasional

Tujuan pendidikan Islam secara nasional ini adalah merujuk pada pendidikan Islam secara universal di atas. Secara eksplisit, tujuan pendidikan Islam secara nasional di Indonesia belum dirumuskan, karena negara Indonesia bukan negara Islam meskipun mayoritas penduduk muslim terbanyak di dunia. Namun tujuan pendidikan Islam tersebut dapat dirujuk pada Undang-Undang Nomor 20 tahun 2003 tentang Sistem Pendidikan Nasional yaitu "membentuk manusia yang beriman, bertakwa, berakhlak mulia. Memiliki ilmu pengetahuan dan teknologi, memiliki keterampilan, sehat jasmani dan rohani, memiliki seni dan bertanggung jawab bagi masyarakat, bangsa dan negara". ${ }^{26}$

c) Tujuan Pendidikan Islam secara Institusional

Tujuan pendidikan Islam secara institusional adalah tujuan pendidikan yang dirumuskan oleh lembaga pendidikan Islam mulai dari tingkat kanak-kanak sampai dengan perguruan tinggi sesuai dengan kebutuhan dan tetap mengacu pada tujuan pendidikan secara universal. ${ }^{27}$

d) Tujuan Pendidikan Islam pada Tingkat Program Studi

Tujuan pendidikan Islam pada tingkatan ini adalah tujuan pendidikan tersebut harus disesuaikan dengan program studi sehingga dapat melahirkan alumni-alumni yang kompeten dibidang tersebut. ${ }^{28}$

e) Tujuan pendidikan Islam pada Tingkat Mata Pelajaran

Tujuan pendidikan Islam pada tingkatan ini yaitu tujuan pendidikan yang harus didasarkan pada tercapai pemahaman, penghayatan dan pengamalan ajaran Islam yang terdapat pada pelajaran tertentu. misalnya tujuan mata pelajaran tafsir yaitu agar peserta didik dapat memahami, menghayati dan mengamalkan ayat-ayat al-Qur"an secara benar, mendalam dan komprehensif. ${ }^{29}$

f) Tujuan Pendidikan Islam pada Tingkat Pokok Bahasan

Tujuan pendidikan Islam pada tingkatan ini yaitu tujuan pendidikan yang didasarkan pada tercapainya kecakapan (kompetensi) utama dan kompetensi dasar pada

\footnotetext{
${ }^{25}$ Abuddin Nata, Ilmu Pendidikan Islam Edisi Pertama, h. 63.

${ }^{26}$ Undang-undang Nomor 20 Tahun 2003 tentang Sistem Pendidikan Nasional

${ }^{27}$ Abuddin Nata, Ilmu Pendidikan Islam Edisi Pertama, h. 64.

${ }^{28}$ Ibid. h. 65.

${ }^{29}$ Ibid. h. 65.
} 
pokok bahasan tersebut. Misalnya pokok bahasan tentang tarjamah, maka kompetensi dasarnya adalah agar siswa memiliki kemampuan menerjemahkan ayat-ayat al-Qur"ean secara benar dan sesuai dengan kaidah-kaidah penerjemahan. ${ }^{30}$

Berdasarkan uraian tujuan pendidikan Islam yang ditawarkan oleh Abuddin Nata di atas, sangat nampak bahwa dalam hal tujuan pendidikan Islam epistemologi yang digunakan adalah pola induktif. Induktif adalah pola pikir dengan pandang atau melihat sesuatu secara luas dan umum kemudian dikerucutkan menjadi khusus dan terbatas.

\section{E. Kurikulum dalam Pendidikan Islam Perspektif Abuddin Nata}

a. Asas-asas Kurikulum

Secara teoritis, kurikulum memiliki asas-asas sebagai respon terhadap realitas kehidupan masyarakat. Abuddin Nata mengatakan ada empat asas kurikulum yang harus diperhatikan oleh pengambil kebijakan dalam pendidikan khususnya pendidikan Islam. Kiranya asas ini menjadi bahan acuan yang perlu dipertimbangkan dan diperhatikan dalam merumuskan kurikulm. asas-asas tersebut yaitu: asas filosofis, asas sosiologis, asas organisatoris dan asas psikologis. ${ }^{31}$

1) Asas filosofis memiliki peran sebagai penentu tujuan umum pendidikan.

2) Asas sosiologis memiliki peran sebagai dasar untuk menentukan apa saja yang akan dipelajari sesuai dengan kebutuhan masyarakat, kebudayaan, perkembangan ilmu pengetahuan dan teknologi.

3) Asas organisatoris memiliki peran menjadi dasar dalam menyusun mata pelajaran, penentuan luas dan urutan mata pelajaran.

4) Asas psikologis memiliki peran menjadi prinsip dalam memahami perkembangan dan kebutuhan anak didik dalam berbagai aspeknya, cara menyampaikan bahan pelajaran yang mudah dicerna dan dipahami anak didik sesuai dengan tahap perkembangannya.

Lebih jauh Abuddin Nata mengatakan bahwa kurikulum dalam pendidikan Islam merupakan alat, sarana untuk mendidik generasi muda dengan baik dan juga membuka jalan untuk mengembangkan bakat, kekuatan dan menyiapkan generasi penerus dengan baik untuk melaksanakan fungsinya sebagai khalifah di muka bumi. ${ }^{32}$

\footnotetext{
${ }^{30}$ Ibid. h. 65.

${ }^{31}$ Abuddin Nata, Filsafat Pendidikan Islam, Cet. ke-2, (Jakarta: Logos Wacana Ilmu, 1997), h. 125.

${ }^{32}$ Abuddin Nata, Filsafat Pendidikan Islam Edisi Baru, h. 179.
} 
FARABI

Jurnal Pemikiran Konstruktif Bidang Filsafat dan Dakwah

ISSN $1907-0993$

E ISSN $2442-8264$

Vol. 18 No. 2, Desember 2018

b. Ciri-ciri kurikulum dalam Pendidikan Islam

Abuddin Nata mengatakan bahwa ada lima ciri kurikulum pendidikan Islam yaitu sebagai berikut:

1) Menonjolkan tujuan agama dan akhlak pada berbagai tujuan, metode, alat dan teknik.

2) Meluas cakupannya dan menyeluruh kandungannya. Maksudnya adalah mencerminkan semangat, pemikiran dan ajaran yang menyeluruh dan memperhatikan segala aspek anak didik baik intelektual, psikologis, sosiologis dan spiritual.

3) Bersikap seimbang dan memperhatikan aspek individu dan sosial, lahir dan bathin, dunia dan akhirat.

4) Bersikap menyeluruh dalam menata mata pelajaran yang diperlukan oleh anak didik.

5) Kurikulum disusun, disesuaikan dan bakat minat anak didik. ${ }^{33}$

Pada dasarnya, kurikulum pendidikan Islam yang ditawarkan oleh Abuddin Nata harus bersifat integral antara dasar agama, filsafat, psikologi dan sosiologi. Secara keseluruhan aspek tersebut harus tercantum dalam merumuskan kurikulum agar saling menguatkan antara satu aspek dan aspek lainnya.

\section{F. Evaluasi dalam Pendidikan Islam Perspektif Abuddin Nata}

Evaluasi merupakan sebuah proses yang membandingkan situasi yang ada dengan ukuran tertentu. sehingga dengan demikian, dengan adanya evaluasi akan memudahkan untuk mendapatkan informasi dan menyusun penilaian dalam rangka mengambil sebuah keputusan. Evaluasi dalam tataran pendidikan tidak hanya menentukan hasil belajar siswa dalam suatu jenjang pendidikan tertentu, tetapi juga berkenaan dengan penilaian segala aspek yang mempengaruhi hasil belajar siswa tersebut.

Berdasarkan uraian di atas, dapat disimpulkan bahwa evaluasi pendidikan adalah suatu kegiatan yang didalamnya berisi pengukuran dan penilaian utnuk mengukur keberhasilan pendidikan dari berbagai aspek yang saling berkaitan.

a. Fungsi Evaluasi

Proses belajar mengajar tidak bisa dilepaskan dari evaluasi. Sebab evaluasi dalam proses belajar merupakan komponen akhir dari keseluruhan proses belajar mengajar. Oleh karena itu, evaluasi memiliki fungsi yang penting dan tidak bisa dilepaskan dari yang namanya belajar mengajar. Berikut ini beberapa model evaluasi dalam proses belajar mengajar sebagai berikut:

\footnotetext{
${ }^{33}$ Ibid. h. 182.
} 
1) Evaluasi berfungsi sebagai selektif yaitu guru akan mudah untuk melakukan seleksi atau penilaian terhadap siswanya.

2) Evaluasi berfungsi sebagai diagnostik yaitu guru menggunakan metode untuk meneliti atau mendiagnosa kelemahan siswa dengan melihat hasil belajar siswa tersebut.

3) Evaluasi berfungsi sebagai penempatan yaitu sebuah metode dimana siswa belajar sendiri dengan menggunakan sebuah paket belajar baik itu modul atau paket belajar lainnya.

4) Evaluasi berfungsi sebagai pengukur keberhasilan yaitu untuk mengetahui sejauh mana sebuah sistem berhasil diaplikasikan. ${ }^{34}$

b. Syarat dan Prinsip Evaluasi

Adapun prinsip-prinsip evaluasi dalam proses pendidikan yaitu sebagai berikut: 1) kontinuitas atau berkesinambungan adalah keberlangsungan evaluasi dalam kurun waktu tertentu yang dilaksanakan secara terus-menerus; 2) komprehensif (menyeluruh) adalah materi evaluasi yang mencakup kepribadian, ketajaman ingatan, pemahaman, ketulusan, kerajinan, sikap kerja, tanggung jawab atau dikenal dengan istilah kognitif, afektif dan psikomotorik; dan 3) objektifitas adalah keterkaitan dengan realitas dan tidak dipengaruhi oleh sesuatu yang sifatnya emosional dan irasional serta tidak ada hubungannya dengan kegiatan belajar. ${ }^{35}$

c. Sasaran Evaluasi

Untuk melakukan evaluasi dalam proses pendidikan, maka seorang pendidik harus mengetahui aspek apa saja yang akan menjadi sasaran evaluasi. Pada umumnya ada tiga sasaran evaluasi dalam proses pendidikan menurut Abuddin Nata yaitu:

1) Aspek tingkah laku adalah segala sesuatu yang menyangkut sikap, minat, bakat, perhatian, keterampilan sebagai akibat dari proses belajar mengajar.

2) Aspek pendidikan adalah pemahaman terhadap materi yang diberikan oleh guru dalam proses belajar mengajar.

3) Aspek yang menyangkut persoalan pembelajaran yaitu harus menyadari bahwa proses belajar mengajar perlu menjadi perhatian secara khusus dari guru. Sebab baik tidaknya proses belajar mengajar akan sangat menentukan baik tidaknya hasil belajar. $^{36}$

\footnotetext{
${ }^{34}$ Abuddin Nata, Filsafat Pendidikan Islam Edisi Baru, h. 188-189.

${ }^{35}$ Abuddin Nata, Filsafat Pendidikan Islam Edisi Baru, h. 192.

${ }^{36}$ Ibid. h. 194-195.
} 
Ketiga sasaran tersebut di atas sangat penting untuk dievaluasi secara komprehensif. Sebab antara aspek satu dan yang lainnya saling mempengaruhi sebagai bagian dari pelaksanaan dalam dunia pendidikan.

\section{G. Komponen dalam Pendidikan Islam Perspektif Abuddin Nata}

a. Pendidik Perspektif Abuddin Nata

1) Pengertian Pendidik

Pendidik dalam Kamus Besar Bahasa Indonesia memiliki makna orang yang mendidik. ${ }^{37}$ Dalam bahasa Arab, banyak dijumpai kata-kata yang bermakna guru atau pendidik yaitu: ustadz, mudarris, mu'allim dan mu'addib. Kata ustadz adalah bentuk mufrad (tunggal) yang dalam bentuk jamak menjadi asatidz yang berarti guru dan profesor (gelar akademik) yang digunakan dalam kapasitas intelektual, pelatih, penulis dan penyair. Adapun kata mudarris berarti guru, pelatih dan dosen. Sedangkan kata mu'allim berarti guru, pelatih, pemandu. Selanjutnya mu'addib berarti pendidik. ${ }^{38}$

Pengertian yang lazim digunakan yaitu pendidik merupakan orang yang bertanggung jawab memberikan pertolongan pada peserta didik dalam perkembangan baik jasmani dan rohani. Semua itu dengan harapan peserta didik mencapai tingkat kedewasaan, mampu berdiri sendiri dan mandiri dalam menjalankan fungsinya sebagai hamba dan khalifah Allah swt. ${ }^{39}$

Kata-kata yang beragam dalam pengertian tersebut di atas, menunjukkan adanya perbedaan ruang gerak dan lingkungan di mana pengetahuan dan keterampilan tersebut diberikan. Apabila proses pendidikan terjadi di sekolah, maka pendidik disebut sebagai guru, apabila proses pendidikan di perguruan tinggi, maka pendidik disebut dosen atau profesor, apabila proses pendidikan di rumah, maka pendidik disebut pembimbing atau tutor dan apabila proses pendidikan dipusat-pusat latihan maka pendidik disebut trainer. ${ }^{40}$

\footnotetext{
${ }^{37}$ W.J.S Poerwadarminta, Kamus Umum Bahasa Indonesia, Cet. ke-12, (Jakarta: Balai Pustaka, 1991), h. 250.

${ }^{38}$ Abuddin Nata, Filsafat Pendidikan Islam Edisi Baru, (Jakarta: Gaya Media Pratama, 2005), h. 113. Lihat juga Askar, Kamus Arab-Indonesia al-Azhar, Cet. ke-2, (Jakarta: Senayan Publishing, 2010), h. 11, 279 dan 639.

${ }^{39}$ Abuddin Nata, Ilmu Pendidikan Islam Edisi Pertama, Cet. ke-2, (Jakarta: Kencana Prenada Media Group, 2012), h. 159.

${ }^{40}$ Abuddin Nata, Filsafat Pendidikan Islam Edisi Baru, h. 113-114.
} 
Adapun pengertian pendidik secara istilah sebagaimana yang dikutip Abuddin Nata dalam bukunya Ahmat Tafsir mengatakan bahwa pendidik adalah orang yang paling bertanggung jawab melakukan proses pendidikan baik itu orang tua (informal) maupun guru (formal). Tanggung jawab tersebut dipicu oleh dua hal yaitu: 1) kodrat, sebab orang tua ditakdirkan oleh Allah swt bertanggung jawab dalam mendidik anakanak mereka sebagai generasi penerus; dan 2) adanya kepentingan orang tua terhadap perkembangan anak yaitu sukses atau tidaknya seorang anak ditentukan oleh campur tangan orang tua. ${ }^{41}$

Al-Qur"an sebagai sumber hukum primer yang utama dan pertama dalam Islam, telah memberikan isyarat tentang seorang guru harus profesional dalam menjalankan tugasnya. Isyarat tersebut sebagai berikut:

a) Guru yang profesional adalah yang terpercaya, menjaga amanah, dan merawat sesuatu dengan baik dan benar.

b) Guru harus memiliki keahlian.

c) Guru profesional selalu bertindak adil. ${ }^{42}$

Berdasarkan beberapa penjelasan di atas, dapat dipahami bahwa kata pendidik secara fungsional menunjukkan pada seseorang yang melakukan kegiatan pembelajaran dan memberikan pengetahuan, keterampilan, pengalaman dan segala apa yang dibutuhkan untuk menumbuhkan potensi, bakat dan minat yang terdapat pada peserta didik. Selain itu juga, pengertian guru atau pendidik selalu dikaitkan dengan bidang tugas atau pekerjaan yang harus dilakukannya. Hal ini jelas menunjukkan bahwa pengertian guru atau pendidik tersebut merupakan profesi atau keahlian yang melekat pada seseorang yang tugasnya berkaitan dengan proses pendidikan. Selain itu, keprofesionalan seorang guru bukan ditunjukkan dengan keahlian, kemahiran dalam melakukan sesuatu, melainkan juga mampu berlaku adil, tanggung jawab dan amanah.

2) Kedudukan Pendidik

Kedudukan dan fungsi guru sebagai pendidik sebagaimana yang tertuang dalam UU Nomor 14 tahun 2005 tentang guru dan dosen yaitu "sebagai tenaga profesional pada jenjang pendidikan dasar, pendidikan menengah pertama, pendidikan menengah atas dan pendidikan anak usia dini pada jalur pendidikan

\footnotetext{
${ }^{41}$ Lihat Ahmad Tafsir, Ilmu Pendidikan dalam Perspektif Islam, Cet. ke-19, (Bandung: PT Remaja Rosdakarya, 2010), h. 74.

${ }^{42}$ Abuddin Nata, Kapita Selekta Pendidikan Islam: Isu-isu Kontemporer tentang Pendidikan Islam, h. 222-224.
} 
formal yang diangkat sesuai deng an peraturan perundang-undangan. ${ }^{43}$ Selain itu, guru juga berfungsi sebagai tenaga profesional untuk meningkatkan martabat dan peran guru sebagai agen pembelajaran untuk meningkatkan mutu pendidikan Nasional. $^{44}$

3) Syarat-syarat Menjadi Tenaga Pendidik

Syarat-syarat untuk menjadi tenaga pendidik dalam lembaga pendidikan baik dosen dan guru sebagaimana yang dimaksud dalam UU Nomor 14 tahun 2005 tentang Guru dan Dosen harus memenuhi empat kriteria kompetensi yaitu:

a. Kompetensi pedagogik.

b. Kompetensi profesional.

c. Kompetensi sosial. ${ }^{45}$

d. Kompetensi kepribadian. ${ }^{46}$

Berdasarkan uraian kompetensi guru tersebut, dapat dipahami bahwa seorang guru harus membekali diri baik fisik dan non fisik, lahir dan batin serta wawasan intelektual yang memadai sebagai agen perubahan yang mampu melahirkan generasi sebagai pelanjut estafet dan juga dalam rangka mewujudkan cita-cita mulia yaitu mencerdaskan kehidupan berbangsa, bernegara dan bermasyarakat.

4) Sifat-sifat Pendidik

Ada beberapa sifat yang harus dimiliki oleh seorang pendidik dalam proses pendidikan. Sifat-sifat guru ${ }^{47}$ tersebut adalah sebagai berikut:

a. Seorang guru harus memiliki sifat zuhud.

b. Seorang guru harus memiliki jiwa yang bersih dari sifat dan akhlak yang buruk.

c. Seorang guru harus ikhlas dalam melaksanakan tugas.

d. Seorang guru harus memiliki sifat pemaaf terhadap muridnya.

e. Seorang guru harus memiliki sifat seorang bapak.

f. Seorang guru harus mengetahui bakat, tabiat dan watak muridnya.

g. Seorang guru harus menguasai bidang studi yang akan diajarkan.

Sifat-sifat guru tersebut di atas dapat dibagi menjadi dua bagian yaitu: 1) sifat yang berkaitan dengan kepribadian dan 2) sifat yang berkenaan keahlian akademik. ${ }^{48}$

\footnotetext{
${ }^{43}$ Undang-Undang Nomor 14 tahun 2005 tentang Guru dan Dosen, Pasal 2, h. 4.

${ }^{44}$ Undang-Undang Nomor 14 tahun 2005 tentang Guru dan Dosen Pasal 4, h. 5.

${ }^{45}$ Abuddin Nata, Menuju Sukses Sertifikasi Guru dan Dosen, (Jakarta: Fazamedia, 2009), h. 40.

${ }^{46}$ Undang-Undang Nomor 14 tahun 2005 tentang Guru dan Dosen Pasal 10, h. 6. Lihat juga Abuddin Nata, Ilmu Pendidikan Islam Edisi Pertama, Cet. ke-2, (Jakarta: Kencana Prenada Media Group, 2012), h. 167.

${ }^{47}$ Abuddin Nata, Filsafat Pendidikan Islam Edisi Baru, h. 123-128.

${ }^{48}$ Ibid. h 129.
} 
FARABI

Jurnal Pemikiran Konstruktif Bidang Filsafat dan Dakwah

ISSN $1907-0993$

E ISSN $2442-8264$

Vol. 18 No. 2, Desember 2018

\section{b. Peserta Didik Perspektif Abuddin Nata.}

1. Pengertian Peserta Didik

Dalam Islam, dikenal tiga istilah yang paling banyak menunjukkan atau sering digunakan pada anak didik. Ketiga kosakata tersebut yaitu: tilmidz (jamaknya talamidz), thalib (jamaknya thullab) dan muta'allim .

Secara etimologi, tilmidz (jamaknya talamidz) yang berarti murid laki-laki dan tilmidzah (jamaknya talamidzah) berarti murid perempuan. Istilah ini lebih banyak digunakan untuk menunjuk pada peserta didik ditingkat Madrasah awaliyah atau sekolah permulaan pada Taman Kanak-Kanak (TK) atau Taman Pengajian al-Qur'an dan yang sejenisnya. istilah tilmidz lebih banyak digunakan untuk menunjukan peserta didik pada sekolah dasar mulai dari Ibtidaiyah sampai Aliyah. ${ }^{49}$

Sedangkan istilah thalib berasal dari kata thalab-yathlubu-thalaban-thaliban yang secara harfiah berarti orang yang mencari sesuatu. Dalam istilah tasawuf, thalib adalah orang yang sedang menempuh jalan spiritual dengan menempa diri untuk memperoleh derajak sufi. Istilah thalib untuk menunjukan makna peserta didik lebih banyak digunakan pada jenjang pendidikan diperguruan tinggi. ${ }^{50}$ Adapun istilah muta'allim, berasal dari kata 'allama-yu'allimu-muta'alliman yang secara harfiah berarti orang yang sedang menuntu ilmu.

Berdasarkan penjelasan defenisi di atas, secara harfiah ketiga istilah tersebut memiliki persamaan yaitu mengacu atau menunjuk kepada aktifitas seseorang yang tengah menempuh dunia pendidikan pada jenjang pendidikan. Perbedaannya hanyalah pada penggunaan istilah tersebut. Pada sekolah yang tingkatnya seperti SD digunakan istilah murid, sedangkan tilmidz digunakan pada sekolah tingkat SLTP SLTA dan istilah thalib lebih digunakan pada perguruan tinggi.

\section{Karakteristik Peserta Didik}

Karakteristik peserta didik dapat dibagi kedalam empat kategori besar sebagai berikut $^{51}$

a) Berdasarkan Tingkat Usia.

b) Berdasarkan Teori Fitrah.

c) Berdasarkan Tingkat Kecerdasan.

d) Berdasarkan Kondisi Sosial, Ekonomi dan Budaya.

\footnotetext{
${ }^{49}$ Abuddin Nata, Ilmu Pendidikan Islam Edisi Pertama, h. 173-174.

${ }^{50}$ Ibid. h. 174.

${ }^{51}$ Ibid. h. 175-181.
} 
$F A R A B I$

Jurnal Pemikiran Konstruktif Bidang Filsafat dan Dakwah

ISSN $1907-0993$

E ISSN $2442-8264$

Vol. 18 No. 2, Desember 2018

\section{Akhlak Peserta Didik}

Pada dasarnya akhlak peserta didik tersebut terbagi dalam tiga kategori besar yaitu akhlak terhadap Allah swt, akhlak terhadap sesama manusia dan terhadap lingkungan sekitar. Akhlak peserta didik terhadap Allah swt yaitu tentang kepatuhan atas perintah dan larangan Allah swt. Adapun akhlak peserta didik terhadap sesama manusia yaitu taat kepada orang tua dan guru selama bukan perkara maksiat, taat kepada pemerintah, menghargai teman, kerabat dan adat istiadat yang positif dalam tatanan kehiduapan bermasyarakat. Sedangkan akhlak peserta didik terhadap lingkungan yaitu menjaga alam dan kehidupan sosial seperti menjaga kebersihan, ketertiban, keindahan, keamanan dan kenyamanan. ${ }^{52}$

Ada beberapa akhlak yang harus dimiliki oleh seorang penuntut ilmu. Asma Hasan Fahmi menguraikan tentang beberapa akhlak peserta didik sebagaimana yang dikutip oleh Abuddin Nata sebagai berikut ${ }^{53}$ :

a. Seorang penuntut ilmu (anak didik) harus membersihkan hati dari kotoran dan penyakit jiwa.

b. Seorang penuntut ilmu (anak didik) harus mempunyai tujuan menuntut ilmu dalam rangka menghiasi jiwa dengan mendekatkan diri kepada Allah swt dan semata-mata mengharapkan ridha-Nya.

c. Seorang penuntut ilmu (anak didik) harus tabah dan sabar dalam proses menuntut ilmu pengetahuan kapan saja dan di manapun ia berada dalam rangka membekali diri untuk meraih kehidupan yang bahagia di dunia dan di akhirat.

d. Seorang penuntut ilmu (anak didik) wajib menghormati guru dan berusaha meraih kerelaan dan keikhlasan guru.

Berkaitan dengan peserta didik dalam pendidikan Islam dan beberapa penjelasan di atas, maka ada beberapa aspek yang perlu menjadi perhatian dan bahan perbaikan yaitu: 1) seorang didik harus memahami secara komprehensif terhadap kondisi peserta didik. Oleh karenanya perlu memadukan antara materi pelajaran dengan metode yang akan menciptakan suasana belajar yang kondusif, efisien dan berjalan dengan lancar; 2) seorang pendidik harus memahami secara utuh akan kondisi peserta didik yang memiliki bakat, tingkat kecerdasan, hobi, sosial ekonomi dan budaya yang berbeda antara satu dan yang lainnya; dan 3) memahami akhlak

\footnotetext{
${ }^{52}$ Abuddin Nata, Ilmu Pendidikan Islam Edisi Pertama, h. 182.

${ }^{53}$ Abuddin Nata, Filsafat Pendidikan Islam Edisi Baru, h. 134-135.
} 
mulia baik itu yang berkaitan dengan akhlak kepada Allah swt, akhlak kepada sesama manusia dan akhlak kepada lingkungan sekitar.

c. Metode dan Strategi Pembelajaran dalam Pendidikan Islam Perspektif Abuddin Nata

Berkaitan dengan metode dan strategi pembelajaran dalam rangka mewujudkan pendidikan yang bermutu dan berkualitas, ada beberapa aspek dalam strategi pembelajaran yang disorot oleh Abuddin Nata. Aspek-aspek dalam strategi pembelajaran tersebut sebagai berikut:

1. Metode Pengajaran

a) Pengertian Metode Pengajaran dan Pendidikan

Metode dapat diartikan sebagai upaya dalam menyampaikan sesuatu gagasan, pikiran atau wawasan secara sistematis yang didasarkan pada teori, konsep dalam berbagai disiplin ilmu yang terkait baik itu sosiologi, psikologi, manajemen dan lain-lain. ${ }^{54}$

Adapun pengajaran dapat dipahami sebagai sebuah upaya menjelaskan dan mentransformasikan berbagai teori, konsep, prinsip yang terdapat dalam mata pelajaran baik fisika, kimia, ekonomi, biologi dan lain-lain. ${ }^{55}$

Berdasarkan penjelasan di atas, dapat dipahami bahwa metode adalah cara dalam menyampaikan sebuah teori dan konsep kepada peserta didik. Sedangkan pengajaran adalah memberikan wawasan kognitif pada peserta didik dalam rangka menumbuhkan keterampilan dan bakat. Sehingga peserta didik memiliki wawasan tentang suatu disiplin ilmu.

b) Macam-macam Metode Pengajaran

Berkaitan dengan metode pengajaran, Abuddin Nata mengungkapkan beberapa metode yang pada umumnya sering digunakan dalam proses belajar mengajar. Berbagai macam metode pengajaran tersebut adalah sebagai berikut:

1. Metode Ceramah. Metode dengan cara menyajikan pelajaran dengan penuturan dan penjelasan secara langsung oleh guru kepada peserta didik. ${ }^{56}$

2. Metode Tanya Jawab. Metode tanya jawab ialah menyajikan pelajaran dalam bentuk pertanyaan yang dikemukakan oleh guru yang harus dijawab oleh siswa. $^{57}$

\footnotetext{
${ }^{54}$ Abuddin Nata, Perspektif Islam tentang Strategi Pembelajaran, Cet. ke-2, (Jakarta: Kencana Prenada Media Group, 2011), h. 176.

${ }^{55}$ Ibid. h. 176.

${ }_{57}^{56}$ Ibid. h. 181 .

${ }^{57}$ Ibid. h. 182.
} 
3. Metode Demonstrasi. Penyajian pelajaran dengan metode ini ialah memperagakan atau mempertunjukkan kepada peserta didik tentang suatu proses, situasi yang sedang dipelajari baik secara langsung maupun tiruan semata. $^{58}$

4. Metode Penugasan. Cara penyajian pelajaran dengan metode ini ialah guru memberikan tugas tertentu pada peserta didik. Penugasan tersebut sebagai bentuk latihan agar ketika berhadapan dengan realitas sosial, peserta didik telah terbiasa dengan tugas-tugas yang ada. ${ }^{59}$

5. Metode Pemecahan Masalah. Cara penyajian pelajaran dengan metode ini ialah menjadikan masalah sebagai titik tolak pembahasan yang akan diuraikan, dianalisis dan disimpulkan sebagai upaya mencari solusi dan jawaban yang sesuai dengan masalah tersebut. ${ }^{60}$

6. Metode Diskusi. Cara penyajian pelajaran dengan menggunakan metode ini ialah dengan menyajikan suatu masalah untuk dibahas dan didiskusikan bersama. Diskusi akan terjadi bila terjadi kesenjangan antara apa yang diharapkan dengan kenyataan yang ada. ${ }^{61}$

7. Metode Simulasi. Cara penyajian pelajaran dengan metode ini ialah berpurapura atau situasi menyerupai dalam proses belajar dengan tujuan memperoleh pemahaman terhadap teori, konsep dan keterampilan tertentu. ${ }^{62}$

8. Metode Eksperimen. Cara penyajian dengan metode ini ialah menugaskan siswa untuk melakukan suatu percobaan dengan mengalami dan membuktikan sendiri. $^{63}$

Berdasarkan beberapa uraian di atas, bahwa metode yang pertama dalam pengajaran tersebut pada umumnya telah banyak digunakan dewasa ini. sementara metode yang kedua lebih kepada praktek dan membutuhkan komitmen yang tinggi.

2. Komponen dalam Strategi Pembelajaran

Ada dua kata yang harus dibedakan pengertiannya yaitu belajar dan pembelajaran. Belajar adalah upaya mendapatkan pengetahuan, keterampilan,

\footnotetext{
${ }^{58}$ Ibid. h. 183.

${ }^{59}$ Ibid. h. 185.

${ }^{60}$ Ibid. h. 187.

${ }^{61}$ Ibid. h. 188.

${ }^{62}$ Ibid. h. 192.

${ }^{63}$ Ibid. h. 194.
} 
pengalaman dan sikap yang dilakukan dengan memberdayakan seluruh potensi jasmani dan rohani manusia dengan bersumber pada bahan bacaan, informasi, alam semesta dan lain sebagainya. ${ }^{64}$

Sedangkan pembelajaran adalah suatu usaha agar setiap individu dapat belajar dan memiliki kesadaran betapa pentingnya belajar. Hal yang paling penting lainnya adalah menjadikan belajar sebagai kebutuhan pokok yang tidak dapat ditinggalkan. ${ }^{65}$

Pembelajaran pada dasarnya merupakan kondisi atau keadaan yang sengaja diciptakan. Guru yang mengajar dan peserta didik yang belajar. Dari kedua komponen ini maka muncullah yang nama pendidikan sebagai proses belajar mengajar.

\section{d. Lingkungan dalam Pendidikan Islam}

Lingkungan pendidikan Islam adalah suatu institusi atau lembaga dimana pendidikan itu berlangsung. Lingkungan belajar bukan hanya terbatas pada ruangan kelas semata tetapi lingkungan global yang lebih luas dan mendukung terutama lewat teknologi informasi. Sehingga paradigma baru sebuah lembaga pendidikan ialah harus melengkapi diri dengan teknologi informasi yang lengkap dan canggih. ${ }^{66}$

Lingkungan dalam perspektif pendidikan Islam sangat luas. Sebab ia mencakup rumah tangga (informal), masyarakat (nonformal) sampai dengan jenjang sekolah dan perguruan tinggi (formal). ${ }^{67}$

e. Pembiayaan dalam Pendidikan Islam

Abuddin Nata menyatakan bahwa pembiayaan pendidikan secara sederhana dapat dipahami sebagai ongkos yang harus disediakan dan diperlukan dalam menyelenggarakan pendidikan sebagai perwujudan untuk mewujudkan visi, misi, tujuan, sasaran sebuah pendidikan. Selain itu biaya tersebut juga diperlukan untuk infrastruktur, sarana prasarana dan gaji para guru. ${ }^{68}$

Penjelasan di atas terkesan menganut paham materialistik yaitu mengukur sesuatu dengan materi. Akan tetapi harus dipahami bersama bahwa pembiayaan dalam pendidikan bukan segala-galanya, tetapi tanpa adanya pembiayaan dalam pelaksaanaan pendidikan, maka pendidikan tidak akan berjalan lancar dan sulit untuk mencapai visi, misi dan tujuan yang ingin dicapai.

\footnotetext{
${ }^{64}$ Henry Noer Aly, Ilmu Pendidikan Islam, (Jakarta: Logos Wacana Ilmu, 1996), h. 38.

${ }^{65}$ Abuddin Nata, Perspektif Islam tentang Strategi Pembelajaran, h. 205.

${ }^{66}$ Abuddin Nata, Managemen Pendidikan: Mengatasi Kelemahan Pendidikan Islam di Indonesia, h. 154.

${ }^{67}$ Abuddin Nata, Filsafat Pendidikan Islam Edisi Baru, h. 165-172.

${ }^{68}$ Ibid. h. 137.
} 
FARABI

Jurnal Pemikiran Konstruktif Bidang Filsafat dan Dakwah

ISSN $1907-0993$

E ISSN $2442-8264$

Vol. 18 No. 2, Desember 2018

\section{H. Penutup}

Setelah menganalisa pemikiran pendidikan Abuddin Nata, maka penulis menyimpulkan bahwa epistemologi pendidikan Islam Abuddin Nata mengandung muatan humanis yaitu sebuah rumusan pendidikan Islam yang memaksimalkan potensi dan kemampuan akal manusia sebagai makhluk yang sempurna dengan tetap bersandar dan berpijak pada al-Qur"an dan Sunnah. Pola pendidikan Islam yang humanis tersebut menghendaki pola theo-antropho-centries yaitu memadukan usaha manusia dengan izin dan kehendak Allah swt.

Selain itu, Abuddin Nata berusaha menginginkan sebuah model pendidikan Islam yaitu pendidikan Islam yang integralistik-konvergensi. Pendidikan Islam integralistikkonvergensi yang dimaksud adalah keterpaduan dan kesatuan antara konsep al-Qur"an dan Sunnah dengan konteks keindonesiaan sehingga mengarah pada satu tujuan mewujudkan kehidupan yang madani.

\section{DAFTAR PUSTAKA}

Arifin, H.M., Ilmu Pendidikan Islam: Suatu Tinjauan Teoritis dan Praktik Berdasarkan Pendekatan Interdisipliner, Jakarta: Bina Aksara, 1991.

Langgulung, Hasan, Asas-asas Pendidikan Islam, Cet. ke-5, Jakarta: PT. Pustaka Al Husna Baru, 2003.

Mulkhan, Abdul Munir, Paradigma Intelektual Muslim, Cet. ke-1, Yogyakarta: Sipres, 1993.

Munir, Muhammad, dan Ilaihi, Wahyu Ilaihi, Managemen Dakwah, Cet. Ke-2, Jakarta: Kencana Prenada Media Grup, 2009.

Nata, Abuddin, Filsafat Pendidikan Islam Edisi Baru, Jakarta: Gaya Media Pratama, 2005.

---------, Ilmu Pendidikan Islam Edisi Pertama, Cet. ke-2, Jakarta: Kencana Prenada Media Group, 2012.

-Managemen Pendidikan: Mengatasi Kelemahan Pendidikan Islam di Indonesia, Jakarta: Cet. ke-4, Jakarta: Kencana Prenada Media Group, 2012.

----------, Kapita Selekta Pendidikan Islam: Isu-isu Kontemporer tentang Pendidikan Islam, Cet. ke-2, Jakarta: Rajawali Pers, 2013.

---------Perspektif Islam tentang Strategi Pembelajaran, Cet. ke-2, Jakarta: Kencana Prenada Media Group, 2011.

Noer, Henry, Ilmu Pendidikan Islam, Jakarta: Logos Wacana Ilmu, 1996. 
Tafsir, Ahmad, Filsafat Pendidikan Islam, Cet. ke-5, Bandung: PT Remaja Rosdakarya, 2012.

Umar, Bukhari, Ilmu Pendidikan Islam, Cet. ke-2, Jakarta: Amzah, 2011.

Undang-Undang Nomor 14 tahun 2005 tentang Guru dan Dosen Pasal 4, h. 5.

Undang-undang Republik Indonesia No. 20 tahun 2003 tentang Sistem Pendidikan Nasional.

W.J.S Poerwadarminta, Kamus Umum Bahasa Indonesia, Cet. ke-12, Jakarta: Balai Pustaka, 1991.

Yatim, Badri, Sejarah Peradaban Islam: Dirasah Islamiyah II, Jakarta: PT Raja Grafindo Persada, 2005. 